\title{
THE EFFECT OF EMPOWERMENT, EMPLOYEE ENGAGEMENT AND ORGANIZATIONAL COMMITMENT TOWARDS PERFORMANCE OF GOVERNMENTAL-EMPLOYEES OF FINANCIAL-MANAGEMENT
}

\author{
Liz Zeny Merry*, Faroman Syarief** \\ lizzenymerry@gmail.com* \\ faroman.frr@bsi.ac.id**
}

\begin{abstract}
The objectives of this research is to study the influence of empowerment, employee engagement, and organizational commitment on performance of the financial management staffs at Riau Islands Provincial Government. Quantitative approach used in this research with survey method. The samples of this research were 230 staffs selected randomly. The data were obtained by distributing questionnaire and analyzed by using path analysis. The results of research shows that: (1) empowerment, employee engagement and organizational commitment had a positive direct effect on employee performance; (2) empowerment and employee engagement had a positive direct effect on organizational commitment; (3) empowerment have a positive direct effect on employee engagement. The research findings recommend to improve employee performance by improving empowerment, employee engagement and organizational commitment of the financial management staff at Riau Island Provincial Government
\end{abstract}

Keywords: empowerment, employee engagement, organizational commitment, and performance

Realizing good governance with a clear and transparant requires Human Resource support with optimal performance, especially those in charge of managing finance in each agency. As the "Riau Islands" province is one of the local Indonesia-governmental agencies are also required to be able to carry out the management of the budget in accordance with the existing legislation. To realize that they are expected to show optimum performance in the execution of their duties.

In fact, related to financial performance management staff, showing still not optimal. The inspection-results conducted by Governmental Board of Financial Audit in 2015 showed that Financial Statements of "Riau Islands" provincial government still found any problems, such as: Not inadequacy of Government Internal Control System; The weakness of the management of spending on goods, Capital and social assistance; Less orderly asset management; Recording of transactions that are less accurate and not exactly right time; as well as the management of revolving funds is not adequate. It shows there are still weaknesses in the financial management by the existing human resources. On one side, the data obtained from the 
Ministry of Domestic Affairs, known uptake budget Kepri province per August 2015 and only $35 \%$ of which should have absorbed $60 \%$. In general Human Resource administration "Riau Islands" province have an educational background which is quite good. A minimum of $57.69 \%$ of graduates become from undergraduate, diploma-graduate $19.25 \%$, and $12.20 \%$ of high school graduates and below-grades. This condition describes the problems that lead to the problem of human resources government-employees performance in "Riau Islands" province.

There are various underlying problems that caused a lower person's performance in an organization. In this study, researchers examined several factors that can affect the performance of employees, such as empowerment, employee engagement and organizational commitment.

\section{Performance}

Performance is the perform of an employee shown during the implementation of duties and work, so it finished well suits the purpose of the organization. T.V. Rao (2004: 5) argues Performance is what is expected to be delivered by an individual or a set of individuals within a time frame. What is expected to be delivered could be stated in terms of results or effort, tasks and quality, with specification of conditions under which it is to be delivered. Some dimensions of performance according to him i.e. output dimension, input dimension, time dimension, focus dimension, quality dimensions and cost dimension.

Rue et. al. (2016:222) define that Job performance is net effect of an employee's effort as modified by abilities and role (or task) perception.

Lim et. al. (2010:347) define that Performance appraisal is the process of determining how well employees do their job relative to a standard and communicating that information to the employee. Furthermore, he identified several criteria that can be used in the assessment of the performance: the amount of the work, the quality of results of the work, the time completed the work and presence in the workplace.

Sabine Sonnentag and Michael Frese (2002:6) define that Task performance refers to an individual's proficiency with which he or she performs activities which contribute to the organization's technical core. Performance is the ability of a person to show activity that contribute to the basic activities of the organization.

Robin Stuart - Kotze (2006:3) define that Performance is all about doing the right thing at the appropriate time. That performance is about doing the right thing at the right time. Furthermore, Mathis and Jackson (2002: 78) illustrates several dimensions of performance, it is said that the performance is essentially what is done or not done by employee. Employee performance is affecting how much they contribute to the organization which among others, include: quantity of output, quality of output, the output time period, attendance at work, and cooperative attitude.

\section{Empowerment}


Empowerment is the efforts undertaken boss about how efforts to increase the capacity of their employees become more empowered in the task by exploiting all the good-potential that comes from within himself or other resources so as to benefit the organization. Ken Blanchard, et. al. (2012: 4) use the term enable employees. "It is said that empowerment is a process of liberating force in others to achieve stunning results". The point is to free knowledge, experience, and strength of motivation that already exists in everyone, but not taken.

Quick Nelson (2013: 364) argues, "Empowerment means sharing power in such a way that individuals learn to believe in their ability to do the job. The driving area or empowerment is that the individuals closest to the work and to the customers should make the decisions and that this makes the best use of employees' skills and talents."

Luthans (2011: 124) defines empowerment namely: Empowerment is the authority to make decisions within one's area of responsibility without first having to get approval from someone else. He describes empowerment as the authority to make decisions on the responsibility of someone without asking the permission of others. Furthermore it is said there are two characteristics of empowerment, namely: 1) Employees are encouraged to use their own initiative dan 2) Empowered employees are given not only the authority but also the resources, so they are able to make decisions and have the power to get them implemented.

Empowerment by Bob Nelson (2007: 34) that gives employees responsibility and authority to do everything in their own way, can be uplifting them. Employees want to be treated as a member of an organization that is trusted and respected. When they were given the independence and autonomy, not only supervisors can concentrate on other issues, but also the employees themselves could make decisions better, and usually they are more happy to work.

\section{Employee engagement}

Employee engagement is a person's emotional involvement with his work, and which performed success-oriented tasks and jobs.

Employee engagement by Schermerhorn (2013: 403) is defined as a personal initiative and the willingness to 'go the extra mile' at work that attachment as individual initiative and desire to contribute more to the job.

Luthans (2011: 124) writes that engaged employees are those who are emotionally invested in their jobs.

Michael Armstrong (2009: 337) writes: Engagement is job-oriented ... Employee engagement takes place when people at work are interested in and positive, even excited about their jobs and are prepared to go the extra mile to get them done to the best of their ability. An engaged employee as defined by Bevan .et. al. (1997) is someone who is aware of business context, and works closely with colleagues to improve performance within the job for the benefit of the organization. He explained there are several factors that influence employee engagement i.e.: The work itself, The work environment, Leadership, Opportunities for personal growth, and Opportunities to Contribute. 


\section{Organizational commitment}

Organizational commitment is a promise faithfully reflecting employee loyalty, obedience, responsibility, and the desire to be always involved maximally in the organization to realize the values and goals of the organization. Newstorm and Davis (2002: 185) describes the organizational commitment as a form of employee loyality, it is said that the Organizational commitment, or employee loyality, is the degree to which an employee Identifies with the organization and wants to continue Actively participating in it. According to Lim et. al. (2010: 78), Organizational commitment is the degree to which employees believe in and accept organizational goals and desire to remain with the organization. "Mathis and Jackson (2002: 158) describes the organizational commitment is the degree to which employees believe in and accept organizational goals and want to remain with the organization is called organizational commitment.

\section{METHOD}

The research was conducted on the financial management staffs in "Riau Islands" Provincial Government on Esselon level IV as a Technical Officer Supervisory in each agency. This research is quantitatif approach and the method was using survey and The population of 542 persons subsequently taken a sample of 230 persons by using strata proportional sampling techniques (proporsional stratified sampling).

The research instrument tested in advance to assess the validity of the formula product moment correlation and reliability with Cronbach alpha formula. Data analysis using inferential statistical analysis. Descriptive statistical analysis includes the value of the average, median, modus, standard deviation, variance, maximum and minimum scores, the distribution frequency and histogram. Inferential statistical analysis using formulas path analysis. The study evaluated the relationship between variables that were analyzed and measured the effect of one variable to another variable. The study examined four variables, i.e. Empowerment, Employee Engagement, Organizational Commitment and Performance.

The theoretical model of research variables could be seen on the following figure:

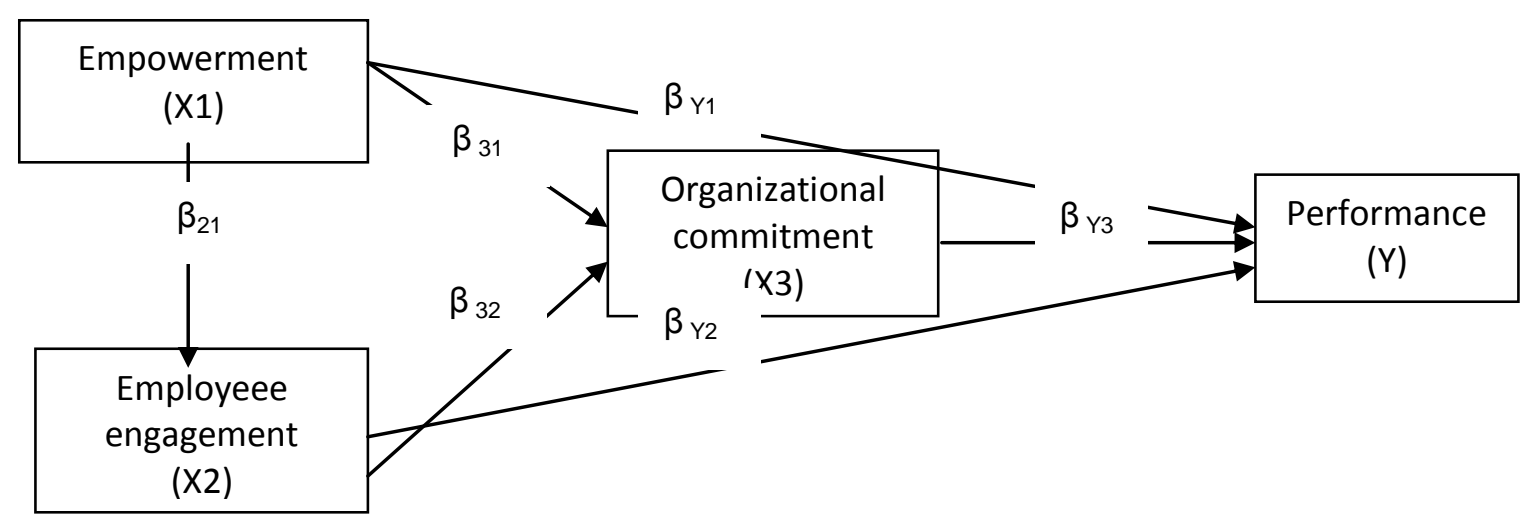


Figure 1. Theoretical Model of Research Variables.

Prior to the data analysis to test the hypothesis, necessary to test requirements analysis, including normality test, linearity test, regression and correlation significance. Subsequently carried out evaluating the hypothesis with path analysis. After conducted Validity and Reliability test towards the respondents data then conducted Normality Test by using Liliefors and linearity test. These tests are purposed to see whether the data can be representative of the population and whether the constructed model has a linear relationship or not.

The evaluation of the path coefficient will be executed after research-hypothesis have been tested in advance by statistical hypothesis, namely:

Hypothesis 1: Hypothesis 2: Hypothesis 3:
$\mathrm{H}_{0}: \beta_{\mathrm{y} 1} \leq 0$
$\mathrm{H}_{0}: \beta_{\mathrm{y} 2} \leq 0$
$\mathrm{H}_{0}: \beta_{\mathrm{y} 3} \leq 0$
$\mathrm{H}_{1}: \beta_{\mathrm{y} 1}>0$
$\mathrm{H}_{1}: \beta_{\mathrm{y} 2}>0$
$\mathrm{H}_{1}: \beta_{\mathrm{y} 3}>0$

Hypothesis 4:

Hypothesis 5:

Hypothesis 6:
$\mathrm{H}_{0}: \beta_{31} \leq 0$
$\mathrm{H}_{0}: \beta_{32} \leq 0$
$\mathrm{H}_{0}: \beta_{21} \leq 0$
$\mathrm{H}_{1}: \beta_{31}>0$
$\mathrm{H}_{1}: \beta_{32}>0$
$\mathrm{H}_{1}: \beta_{21}>0$

\section{RESULTS AND DISCUSSION}

Before calculating the path coefficients, it's necessary to calculate the correlation coefficient between the variables in advance. The calculations show that all the correlation coefficient between variables is positive, indicating that there is a positive relationship between the variables contained in the structural model. The entire value of the correlation coefficient was significant at $\alpha=0.05$.

A summary of the results of path coefficient, can be seen on the following table.

Table 1. Results Summary of Path Coefficient and Its Influence

\begin{tabular}{|ccc|}
\hline No & Variable & Direct influence of path coefficient \\
\hline 1 & X1 towards Y & 0.259 \\
\hline $\mathbf{2}$ & X2 towards Y & 0.286 \\
\hline
\end{tabular}




\begin{tabular}{|ccc|}
\hline $\mathbf{3}$ & $\mathrm{X} 3$ towards Y & 0.330 \\
\hline $\mathbf{4}$ & $\mathrm{X} 1$ towards X3 & 0.420 \\
\hline $\mathbf{5}$ & $\mathrm{X} 2$ towards X3 & 0.294 \\
\hline $\mathbf{6}$ & $\mathrm{X} 1$ towards X2 & 0.531 \\
\hline
\end{tabular}

Based on the results of data analysis, it's obtained a structural equation below :

Sub structural $1: \mathrm{Y}=0.259 \mathrm{X}_{1}+0.286 \mathrm{X}_{2}+0.330 \mathrm{X}_{3}$

Sub structural 2: $\mathrm{X}_{3}=0.420 \mathrm{X}_{1}+0.294 \mathrm{X}_{2}$

Sub structural 3: $\mathrm{X}_{2}=0.531 \mathrm{X}_{1}$

After calculating the path coefficients in Sub Structure 1, 2 and 3, the path diagram could be described as the following;

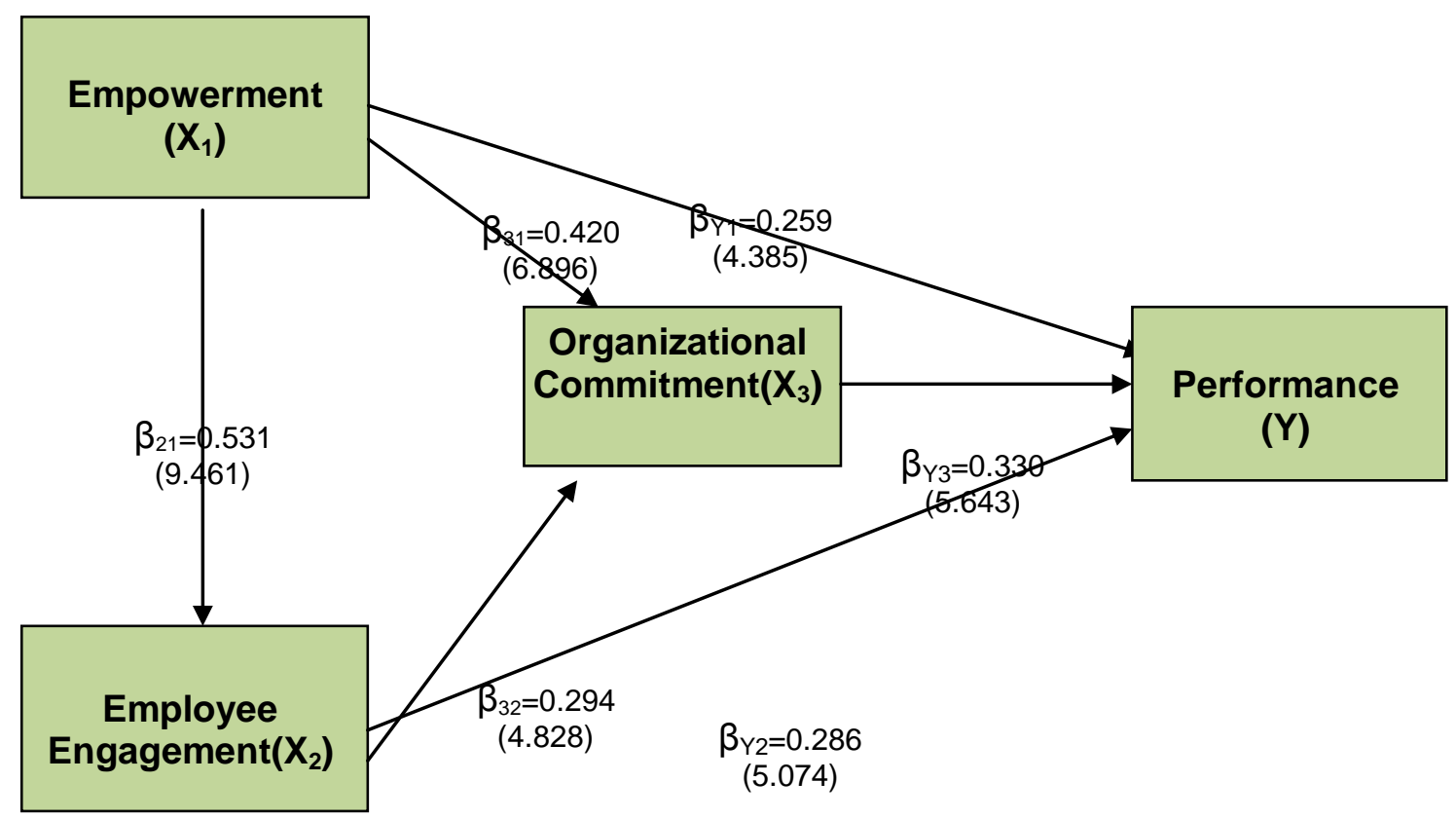

Figure 2. Path diagram of Variable $X_{1}, X_{2}$, and $X_{3}$ towards $Y$

Firstly, from the above calculation of path analysis, further we analyze to determine the acceptance or rejection of the hypothesis. The calculation result of path coefficient shows that empowerment has a direct influence towards employee performance with path coefficient value 
$(\rho Y 1)=0.259$ and $t_{a}$ value $=4.385$, while $t_{\text {tab }}$ for $n=228(n-2)$ on $\alpha=0.05$ is 1.645 . The value of $t_{a}>t_{-t a b}$, then $H_{o}$ is rejected and $\mathrm{H}_{1}$ is accepted. Thus, it can be concluded that empowerment has a positive and direct effect towards employee performance. It means that the increasing of empowerment will improve employee performance.

The second hypothesis test is known that the calculation result of path coefficient shows that employee engagement has a direct influence towards employee performance with path coefficient value $(\rho Y 2)=0.286$ and $t_{a}$ value $=5.074$, while $t_{-t a b}$ for $n=228(n-2)$ on $\alpha=0.05$ is 1.645. The Value of $t_{a}>t_{-t a b}$, then $H_{o}$ is rejected and $H_{1}$ is accepted. Thus, it can be concluded that employee engagement has a positive and direct effect towards employee performance. It means that the increasing of employee engagement will improve employee performance.

The third hypothesis test is known that the calculation result of path coefficient shows that organizational commitment has a direct influence towards employee performance with path coefficient value $\left(\rho Y_{3}\right)=0.330$ and $t_{a}$ value $=5.643$, while $t_{- \text {tab }}$ for $n=228(n-2)$ on $\alpha=0.05$ is 1.645. The Value of $t_{a}>t_{-t a b}$, then $H_{o}$ is rejected and $H_{1}$ is accepted. Thus, it can be concluded that organizational commitment has a positive and direct effect towards employee performance. It means that the increasing of organizational commitment will improve employee performance.

The forth hypothesis test is known that the calculation result of path coefficient shows that empowerment has a direct influence towards organizational commitment with path coefficient value $\left(\rho Y_{31}\right)=0.420$ and $t_{a}$ value $=6.896$, while $t_{-t a b}$ for $n=228(n-2)$ on $\alpha=0.05$ is 1.645. The Value of $t_{a}>t_{-t a b}$, then $H_{o}$ is rejected and $H_{1}$ is accepted. Thus, it can be concluded that empowerment has a positive and direct effect towards organizational commitment. It means that the increasing of empowerment will improve organizational commitment.

The fifth hypothesis test is known that the calculation result of path coefficient shows that employee engagement has a direct influence towards organizational commitment with path coefficient value $\left(\rho Y_{32}\right)=0.294$ and $t_{a}$ value $=4.828$, while $t_{- \text {tab }}$ for $n=228(n-2)$ on $\alpha=0.05$ is 1.645. The Value of $t_{a}>t_{-t a b}$, then $H_{o}$ is rejected and $H_{1}$ is accepted. Thus, it can be concluded that employee engagement has a positive and direct effect towards organizational commitment. It means that the increasing of employee engagement will improve organizational commitment.

The sixth hypothesis test is known that the calculation result of path coefficient shows that empowerment has a direct influence towards employee engagement with path coefficient value $\left(\rho Y_{21}\right)=0.531$ and $t_{a}$ value $=9.461$, while $t_{\text {tab }}$ for $n=228(n-2)$ on $\alpha=0.05$ is 1.645 . The Value of $t_{a}>t_{t a b}$, then $H_{o}$ is rejected and $H_{1}$ is accepted. Thus, it can be concluded that empowerment has a positive and direct effect towards employee engagement. It means that the increasing of empowerment will improve employee engagement.

Furthermore, the results of hypothesis evaluation recapitulated in the following table.

Table 2. Recapitulation of Hypothesis evaluation results 


\begin{tabular}{|c|c|c|c|c|c|c|}
\hline No & Hypothesis & $\begin{array}{l}\text { Test of } \\
\text { Statistic }\end{array}$ & $\begin{array}{l}\text { Path } \\
\text { Coeff }\end{array}$ & $\begin{array}{c}t_{a} \\
d f=230\end{array}$ & $\begin{array}{c}\text { Decission } \\
\text { of Ho }\end{array}$ & Conclusion \\
\hline 1. & $\begin{array}{l}\text { Empowerment }\left(\mathrm{X}_{1}\right) \text { directly } \\
\text { positive effected towards } \\
\text { Performance }(\mathrm{Y})\end{array}$ & $\begin{array}{c}\mathrm{H}_{0}: \beta_{\mathrm{y} 1} \leq \\
0 \\
\mathrm{H}_{1}: \beta_{\mathrm{y} 1}> \\
0\end{array}$ & 0.259 & 4.385 & $\begin{array}{c}\mathrm{H}_{0} \text { Not } \\
\text { accepted }\end{array}$ & $\begin{array}{l}\text { Directly } \\
\text { Effected }\end{array}$ \\
\hline 2. & $\begin{array}{l}\text { Employee Engagement }\left(\mathrm{X}_{2}\right) \\
\text { directly positive effectied } \\
\text { towards Performance }(\mathrm{Y})\end{array}$ & $\begin{array}{c}\mathrm{H}_{0}: \beta_{\mathrm{y} 2} \leq \\
0 \\
\mathrm{H}_{1}: \beta_{\mathrm{y} 2}> \\
0\end{array}$ & 0.286 & 5.074 & $\begin{array}{c}\mathrm{H}_{0} \text { Not } \\
\text { Accepted }\end{array}$ & $\begin{array}{l}\text { Directly } \\
\text { Effected }\end{array}$ \\
\hline 3. & $\begin{array}{l}\text { Organizational Commitment } \\
\left(\mathrm{X}_{3}\right) \text { directly positive effected } \\
\text { towards Performance }(\mathrm{Y})\end{array}$ & $\begin{array}{c}\mathrm{H}_{0}: \beta_{\mathrm{y} 3} \leq \\
0 \\
\mathrm{H}_{1}: \beta_{\mathrm{y} 3}> \\
0\end{array}$ & 0.330 & 5.643 & $\begin{array}{c}\mathrm{H}_{0} \text { Not } \\
\text { Accepted }\end{array}$ & $\begin{array}{l}\text { Directly } \\
\text { Effected }\end{array}$ \\
\hline 4. & $\begin{array}{l}\text { Empowerment }\left(\mathrm{X}_{1}\right) \text { directly } \\
\text { positive effected towards } \\
\text { Organizational Commitment } \\
\left(\mathrm{X}_{3}\right)\end{array}$ & $\begin{array}{c}\mathrm{H}_{0}: \beta_{31} \leq \\
0 \\
\mathrm{H}_{1}: \beta_{31}> \\
0\end{array}$ & 0.420 & 6.896 & $\begin{array}{c}\mathrm{H}_{0} \text { Not } \\
\text { Accepted }\end{array}$ & $\begin{array}{l}\text { Directly } \\
\text { Effected }\end{array}$ \\
\hline 5. & $\begin{array}{lr}\text { Organizational } & \text { Commitment } \\
\left(\mathrm{X}_{2}\right) \quad \text { diredtly } & \text { positive } \\
\text { effected } & \text { towards } \\
\text { Organizational } & \text { Commitment } \\
\left(\mathrm{X}_{3}\right) & \end{array}$ & $\begin{array}{c}\mathrm{H}_{0}: \beta_{32} \leq \\
0 \\
\mathrm{H}_{1}: \beta_{32}> \\
0\end{array}$ & 0.294 & 4.828 & $\begin{array}{c}\mathrm{H}_{0} \text { Not } \\
\text { Accepted }\end{array}$ & $\begin{array}{l}\text { Directly } \\
\text { Effected }\end{array}$ \\
\hline 6. & $\begin{array}{l}\text { Empowerment }\left(\mathrm{X}_{1}\right) \text { directly } \\
\text { positive effected towards } \\
\text { Employee Engagement }\left(\mathrm{X}_{2}\right)\end{array}$ & $\begin{array}{c}\mathrm{H}_{0}: \beta_{21} \leq \\
0 \\
\mathrm{H}_{1}: \beta_{21}> \\
0\end{array}$ & 0.531 & 9.461 & $\begin{array}{c}\mathrm{H}_{0} \text { Not } \\
\text { Accepted }\end{array}$ & $\begin{array}{l}\text { Directly } \\
\text { Effected }\end{array}$ \\
\hline
\end{tabular}

The results of this study indicate that the empowerment has a positive direct effect towards employee performance. Empowerment is an effort to increase the capacity of employees become more empowered in performing their duties. In this case, employer play a role in just doing that as an effort to recognize and exploit the potential within the financial management staff. Presented by Randolph in Luthans (2011: 322), the Empowerment may be defined as recognizing and releasing into the organization the power that people have in their wealth of useful knowledge and internal motivation. In this case the employer will obtain information on 
the members related to what is understood and knowledge possessed by its staff in terms of financial management. In addition, employer can also obtain information about talent or potential that exists in an employee, or knowing the personal motivation of employees at work so as to facilitate employer to manage any potential human resources within the team. If an employee has developed the knowledge and motivation, it will be very useful to be able to complete their tasks properly.

Hypothesis evaluation results indicate that employee engagement has a direct positive effect towards employee performance. It means that the increasing of employee engagement will improve employee performance. In the context of this study, the increasing of employee engagement of Financial Management staff in the Government of Kepri province will improve employee performance.

Employee engagement plays an important role in influencing the performance because employee engagement is an individual internal factor that can provide the strength and encouragement for someone to do something better. Presented Snell and Bohlander (2010: 713), Engaged employees are employees who consistently perform at high levels, are enthusiastic about what they do, and look for better, more efficient ways of doing things. It means that individuals who are tied to their work demonstrated by employees who consistently demonstrate high performance, enthusiastic about what they are doing, and looking for the best, and to find the most efficient way of doing things.

These conditions are important prerequisites so that individuals can show a good performance.

The evaluation results of hypothesis prove that organizational commitment has a positive direct effect towards employee performance. It means that the increase of organizational commitment will have an impact on increasing employee performance. In the context of this study, the strong organizational commitment of employees at the Financial Management in the regional work units of Kepri Provincial Government will provide a significant impact on increasing employee performance.

Organizational commitment has aspects of conviction of the value and purpose of the organization, the desire to survive, the desire to promote the organization, as well as their pride in the organization. In the context of Financial Management at the regional work units of Kepri Provincial Government, organizational commitment shown by the confidence of employees against the values and goals of the organization. Employees looked at in accordance with personal values, not clash, so they were being supportive happen. Employees also receive a variety of policies under the derivative values. As a financial manager employee in this case seeks to support the establishment of clean governance.

Besides it, within commitment of the organization, employees are showing a desire to survive in the organization. As noted by Robbins (2015: 102) define that organizational commitment is the degree to which an employee identifies with a particular organization and its goals and wishes to maintain membership in the organization. According to Becker and Meyer in the Greenberg (2011: 231) explain that Organizational commitment is concerned with the 
degree to which people are involved with their organizations and are interested in remaining within them.

Employees who have committed to the organization are also shown by the desire to promote the organization. Among these want to remind colleagues in order to diligent in work, not only his own, employee also want to encourage other colleagues performing the task of financial management accordance with applicable regulations, contribute actively looking for a solution in the job, willing to share their experiences in order to realize a good cooperation, willing to help other colleagues execute their duties. Denisi and Griffin (2005: 270) argues, Organizational commitment is the degree to which an employee identifies with an organization and is willing to exert effort on behalf of the organization.

Even employees who have higher organizational commitment mentioned more able to face problems in the organization. As it researched by Jamal (2011) demonstrated that individuals with high organizational commitment appear to be more able to face the consequences of conflict from job stress than people with low organizational commitment. So that those who have the organizational commitment is expected to realize the goals and values of the organization.

Cooper (2004: 31) describes the influence of commitment to performance as we consider the important link between commitment and job performance. It is accepted that greater commitment leads to improve work and organizational performance. Most managers believe that real commitment from staff would dramatically improve performance of their business. Interestingly, investigation has found a positive relationship between organizational commitment and output of measures of performance, such as a change in operating profit and sales targets.

The above explanation shows that the commitment is considered as an important factor related with the performance.

\section{CONCLUSION}

Based on the results of research and statistical analysis, it could be concluded: (1) Empowerment directly positive influence towards employee performance. It means that high empowerment will be able to increase employee performance. (2) Employee engagement directly positive influence towards employee performance. It means that high employee engagement will be able to increase employee performance. (3) Organisational Commitment directly positive influence towards employee performance. It means that high organizational commitment will be able to increase employee performance. (4) Empowerment directly positive influence towards organizational commitment. It means that high empowerment will be able to increase organizational commitment. (5) Employee Engagement directly positive influence towards organizational commitment. It means that high employee engagement will be able to increase organizational commitment. (6) Empowerment directly positive influence towards employee engagement. It means that high empowerment will be able to increase employee engagement.

\section{REFERENCES}


Armstrong, Michael. Armstrong's Handbook of Human Resource Management, London and Philadelphia: Kogan Page, 2009.

Blanchard, Ken, John P. Carlos, dan Alan Randolph, The 3 Keys to Empowerment, Surabaya: Mic Publishing, 2012.

Cooper, David J. Improving People Performance in Construction Aldershot: Gower Publishing Limited, 2004.

Cummings, Thomas G dan Christopher G. Worley, Organization Development \& Change, USA: Cengange Learning, 2015.

Denisi and Griffin. Human Resource Management. USA: Houghton Mifflin Company, 2005.

Greenberg, Jerald. Behavior in Organization, England: Pearson Education, 2011.

Jamal, Muhammad. Job Stress, Job Performance and Organizational Commitment in a Multinational Company: An Empirical Study in two Countries, International Journal of Business and Social Science, Vol.2 No.20, November 2011.

Lim, Ghee Soon, Robert L. Mathis, dan John H. Jackson. Human Resource Management An Asia Edition. Singapore: Cengage Learning, 2010.

Luthans, Fred Organizational Behavior, An Evidence-Based Approach, NY: McGraw-Hill, 2011

Mathis dan Jackson, Manajemen Sumber Daya Manusia, Buku 2. Jakarta: Salemba 4, 2002.

Nelson, Bob. 1001 Cara untuk Menjadikan Karywan Bersemangat, 1001 Ways to Energize Employees, terjemahan Arvin Saputra, Batam: Karisma Publishing Group, 2007.

Newstorm, John W. and Keith Davis, Organizational Behavior, United States: McGraw-Hill, 2002 .

Nelson, Quick. Principles of Organizational Behavior; Realities and Challenges. USA: Cengange Learning, 2013

Rao, TV. Performance Management and Appraisal Systems, HR Tools for Global Competitiveness, New Delhi/ Thousand Oaks/ London: Response Books, 2004.

Robbins, Stephen P. and Timothy A. Judge, Organizational Behavior, England: Pearson, 2015.

Rue, et. al. , Human Resources Management, New York: Mc.Graw-Hill, 2016.

Schermerhorn, John R. Jr, Introduction to Management, Singapore: John Wiley \& Sons, Inc, 2013. 
Snell, Scott dan George Bohlander, Principles of Human Resouce Management. South-Western: Cengange Learning, 2010.

Sonnentag, Sabine dan Michael Frese, Psychological Management of Individual Performance, (New Jersey: John Wiley \& Sons, Ltd, 2002.

Stuart, Robin- Kotze, Performance, The Secrets of Successful Behaviour (Great Britain: Prentice Hall, 2006. 